\title{
PENGARUH MOTIVASI, PENGEMBANGAN KARIR DAN KOMPENSASI TERHADAP KEPUASAN KERJA KARYAWAN PT. TOZY SENTOSA ( CENTRO LIFESTYLE DEPARTMENT STORE ) CABANG YOGYAKARTA
}

\author{
Rosianawati Lovendah \\ Fakultas Ekonomi Universitas Sarjanawiyata Tamansiswa Yogyakarta \\ lovendahrosianawati@gmail.com
}

\begin{abstract}
This study aims to determine the Effects of Motivation, Career Development and Compensation Against Employee Satisfaction of PT Tozy Sentosa (Centro Lifestyle Department Store) Branch of Yogyakarta. This is a descriptive study that aims to explain the research variables, namely motivation, career development, compensation and job satisfaction. In this study population were all employees of PT Tozy Sentosa (Centro Lifestyle Department Store) Branch of Yogyakarta which totaled 65 people. As well as sampling techniques strata sampling, which amounts to 40 people .

Based on the results of research conducted, it can be concluded as follows:
\end{abstract}

Results of multiple regression analysis of the Effects of Motivation, Career Development and Compensation Against Employee Satisfaction of PT Tozy Sentosa (Centro Lifestyle Department Store ) Branch of Yogyakarta Is $Y=0.258+0.313 X 1+0.286 X 2+0.315 X 3+e$

Motivation on job satisfaction in the t test, $t$ value of 2.358 with variable motivational significance value of 0.024 Therefore, the significance value is less than $5 \%(0.024<0.05)$ then $H_{a 1}$ accepted, so it can be concluded that there is influence positive and significant correlation between motivation on employee job satisfaction of PT Tozy Sentosa.

Career development toward job satisfaction in the $t$ test, $t$ value career development variables of 2.256 with a significance value of 0.030. Therefore, the significance value is less than 5\% ( 0.030 $<0.05)$ then $H_{a l}$ accepted, so it can be concluded that there is a positive and significant effect between career development on employee job satisfaction of PT Tozy Sentosa.

Compensation for job satisfaction in t-test, that the $t$ value variable compensation of 2.720 with a significance value of 0.010. Therefore, the significance value is less than $5 \%(0.010<0.05)$ then $H_{a l}$ accepted, so it can be concluded that there is a positive and significant effect of the compensation on employee job satisfaction of PT Tozy Sentosa.

Annova test or F test obtained values F calculated at 22.704, while the F table with a significance level of 5\% and a confidence level of $95 \%$ for $d f^{d}=3$ and DF2 $=40-1=39$ is 2.84 , in addition to the significant value of 0.000 . Therefore, the $F$ count $>F$ table $(22.704>2.84)$ and significance value $(0.000<0.05)$, then the hypothesis is accepted so that it can be interpreted that there is a significant influence jointly between motivation, career development and compensation against complacency employee PT Tozy Sentosa.

Keywords : motivation, career development and compensation

\section{PENDAHULUAN}

Dewasa ini pergeseran pola pikir dari product oriented menjadi customer oriented mengakibatkan meningkatnya tuntutan atas pelayanan yang cepat, tepat, murah, adil, berkualitas dan lengkap. Sumber daya manusia sebagai faktor produksi vitalharus ditingkatkan efisiensi, kualitas, dan produktifitasnya.Maka dari itu perusahaan harus mampu menciptakan kondisi yang dapat mendorong untuk mengembangkan dan meningkatkan kemampuannya dengan optimal. Untuk 
mencapai kondisi tersebut perusahaan harus menerapkan kebijakan pengelolaan sumber daya manusia yang baik, antara lain dengan memberikan motivasi, program pelatihan serta pemberian kompensasi kepada karyawannya, sehingga karyawan mendapatkan kepuasan kerja yang optimal.

Kepuasan kerja merupakan salah satu sasaran penting dalam manajemen sumber daya manusia.Seseorang cenderung bekerja dengan penuh semangat apabila kepuasan dapat diperoleh karyawan dari pekerjaannya.Selain itu kepuasan kerja karyawan merupakan kunci pendorong moral, kedisiplinan, dan prestasi kerja karyawan dalam mendukung terwujudnya tujuan perusahaan (Hasibuan, 2003 dalam Prasetyo dan Wahyuddin, 2005).

Mengingat pentingnya pemenuhan kepuasan kerja karyawan bagi pencapaian kinerja individu dan kinerja organisasi, maka penulis tertarik untuk melakukan penelitian terhadap pengaruh faktor motivasi, pengembangan karir, dan kompensasi terhadap kepuasan kerja karyawan pada PT Tozy Sentosa (Centro Lifestyle Departement Store) cabang Yogyakarta. Alasan dipilihnya PT Tozy Sentosa cabang Yogyakarta sebagai objek penelitian adalah karena PT Tozy Sentosa merupakan perusahaan yang bergerak dalam penjualan produk branded fashion dengan pangsa pasar middle up (menengah ke atas), sehingga dalam prakteknya harus didukung oleh sumber daya manusia (karyawan) yang mumpuni untuk menghasilkan layanan yang berkualitas.

Berdasarkan latar belakang, permasalahan dalam penelitian ini dapat dirumuskan sebagai berikut:

1. Apakah ada pengaruh motivasi terhadap kepuasan kerja karyawan PT. Tozy Sentosa (Centro Lifestyle Departement Store) cabang Yogyakarta?

2. Apakah ada pengaruh pengembangan karir terhadap kepuasan kerja karyawan PT. Tozy Sentosa (Centro Lifestyle Departement Store) cabang Yogyakarta?

3. Apakah ada pengaruh kompensasi terhadap kepuasan kerja karyawan PT. Tozy Sentosa (Centro Lifestyle Departement Store) cabang Yogyakarta?

4. Apakah ada pengaruh motivasi, pengembangan karir dan kompensasi secara bersama-sama terhadap kepuasan kerja karyawan PT. Tozy Sentosa (Centro Lifestyle Departement Store) cabang Yogyakarta?

Penelitian ini bertujuan untuk menguji dan menganalisis:

1. Apakah ada pengaruh motivasi terhadap kepuasan kerja karyawan PT. Tozy Sentosa (Centro Lifestyle Departement Store) cabang Yogyakarta?

2. Apakah ada pengaruh pengembangan karir terhadap kepuasan kerja karyawan PT. Tozy Sentosa (Centro Lifestyle Departement Store) cabang Yogyakarta?

3. Apakah ada pengaruh kompensasi terhadap kepuasan kerja karyawan PT. Tozy Sentosa (Centro Lifestyle Departement Store) cabang Yogyakarta?

4. Apakah ada pengaruh motivasi, pengembangan karir dan kompensasi secara bersama-sama terhadap kepuasan kerja karyawan PT. Tozy Sentosa (Centro Lifestyle Departement Store) cabang Yogyakarta?

Hasil penelitian ini diharapkan dapat memberikan manfaat bagi berbagai pihak, antara lain:

1. Bagi PT Tozy Sentosa ( Centro Lifestyle Department Store ) Cabang Yogyakarta

Hasil penelitian ini diharapkan dapat memberikan masukan yang bermanfaat untuk membantu perusahaan dalam mengambil langkah-langkah dengan tujuan meningkatkan produktivitas karyawan, yaitu dengan cara memberikan pelatihan, pengembangan karir, motivasi dan kompensasi yang tepat. Serta dapat mengetahui tingkat kepuasan kerja para karyawannya

2. Bagi Peneliti Lain

Dari hasil penelitian yang dilakukan, diharapkan dapat bermanfaat bagi peneliti lain sebagai bahan referensi dan bahan masukan bagi pihak-pihak berkepentingan terutama yang akan mengadakan penelitian berhubungan dengan permasalahan yang sejenis.

3. Bagi Ilmu Pengetahuan

Dari hasil penelitian yang dilakukan, diharapkan dapat mendorong para peneliti lain untuk lebih meningkatkan, 
mengembangkan dan memperkuat teoriteori tentang kompensasi, motivasi, pengembangan karir dan kepuasan kerja.

\section{LANDASAN TEORI DAN \\ PENGEMBANGANHIPOTESIS \\ Pengertian Motivasi}

Marihot Tua E. H.(2002) mendefinisikan motivasi sebagai faktor-faktor yang mengarahkan dan mendorong perilaku ataukeinginan seseorang untuk melakukan suatu kegiatan yang dinyatakan dalambentuk usaha keras atau lemah

\section{Pengertian Pengembangan Karir}

Menurut Casio dalam buku Bambang Wahyudi (2002) mengatakan bahwa karir adalah "Rangkaian promosi jabatan atau mutasi jabatan yang lebih tinggi dalam jenjang hirarki yang dialami oleh seorang karyawan selama masa kerjanya".

\section{Pengertian Kompensasi}

Menurut Hadari Nawawi (2005) Kompensasi bagi organisasi/perusahaan berarti penghargaan/ganjaran pada para pekerja yang telah memberkan kontsribusi dalam mewujudkan tujuannya, melalui kegiatan yang disebut bekerja.

\section{Pengertian Kepuasan Kerja}

Robbins (2003) dalam Wibowo (2007) mendefinisikan kepuasan kerja sebagai sikap umum terhadap pekerjaan seseorang, yang menunjukkan perbedaaan antara jumlah penghargaan yang diterima pekerja dengan jumlah yang mereka yakini seharusnya mereka terima.

\section{Hipotesis}

. Berdasarkan hasil penelitian yang dilakukan oleh Sugijono ( 2011 ), dengan judul "Pengaruh Persepsi Kompensasi Lingkungan Kerja Kepemimpinan dan Motivasi terhadap Kepuasan Kerja Guru dan Keryawan Sekolah Menengah Kejuruan Tamansiswa Jetis Yogyakarta" menunjukkanbahwa kompensasi berpengaruh secara signifikan terhadap kepuasan kerja pegawai. Keadaan ini dapat dilihatdari hasil perhitungan korelasi antara 2 faktor tersebut, yaitusebesar 2,521.Dan motivasiberpengaruh secara signifikan terhadap kepuasan kerja pegawai yang terihat dari hasil perhitungan korelasi antara 2 faktor tersebut, yaitu 2,647.
Septyaningsih Ekayadi (2010) dalam penelitian dengan judul "Pengaruh Motivasi dan Pengembangan Karir Terhadap Kupuasan Kerja Karyawan Pada PT Rimbajatiraya Citrakarya" menyimpulkan pengembangan karir mempunyai pengaruh yang signifikan terhadap kepuasan kerja karyawan pada PT Rimbajatiraya Citrakarya, hal ini terlihat dari $\mathrm{t}$ hitung penelitian sebesar $7.651>\mathrm{t}$ tabelnya, yaitu sebesar 1.725 .

Penelitian Anwar Prabu yang dipublikasikan pada Jurnal Manajemen dan Bisnis Universitas Sriwijaya Vol 3 tanggal 6 Desember 2005 dengan judul "Pengaruh Motivasi Terhadap Kepuasan Kerja Pegawai BKKBN Kabupaten Muara Enim" menunjukkan hasil bahwakeseluruhan variabel bebas faktor-faktor motivasi secara bersamasama memiliki pengaruhyang signifikan terhadap variabel terikat kepuasan kerja pegawai, yaitu sebesar 50,7\%. Hal ini menunjukkanbahwa semakin tinggi faktorfaktor motivasi yang diberikan maka akan semakin tinggipula kepuasan kerja pegawai.

Sehubungan dengan uraian di atas maka dapat dikemukakan hipotesis dalam penelitian ini adalah sebagai berikut:

H1 : M0tivasi berpengaruh positif dan signifikan terhadap kepuasan kerja karyawan

H2 : Pengembangan Karir berpengaruh positif dan signifikan terhadap kepuasan kerja karyawan

H3 : Kompensasi berpengaruh positif dan signifikan terhadap kepuasan kerja karyawan

H4 : Motivasi, Pengembangan Karir dan Kompensasi secara bersama-sama berpengaruh positif dan signifikan terhadap kepuasan kerja karyawan

\section{Metode Penelitian}

Penelitian yang berjudul " Pengaruh Motivasi, Pengembangan Karir dan Kompensasi Terhadap Kepuasan Kerja Karyawan PT Tozy Sentosa ( Centro Lifestyle Deparment Store ) Cabang Yogyakarta" ini bersifat kuantitatif, dimana pengukuran variabel dilakukan dengan menggunakan daftar pertanyaan secaraterstruktur kepada responden. Jumlah pertanyaan sebanyak 23 pertanyaan. Untukmemperdalam hasil penelitian, penulis 
menggunakan skala likert, yang setiap pertanyaanmempunyai bobot nilai sebagai berikut : Sangat Setuju (Skor 5), Setuju (Skor 4), KurangSetuju (Skor 3), Netral (Skor 2), Sangat Tidak Setuju (Skor 1)

Dalam penelitian ini terdapat dari 3 variabel bebas dansatu variabel terikat.Variabel bebas terdiri atas: Motivasi (X1), Pengembangangkan Karir (X2) dan Kompensasi (X3), Sedangkan variabel terikat dalam penelitian ini adalah Kepuasan Kerja (Y).

Menurut Sugiyono (2002), populasi adalah wilayahgeneralisasi yang terdiri atas: obyek/subyek yang mempunyai kualitas dankarakteristik tertentu yang ditetapkan oleh peneliti untuk dipelajari dan kemudianditarik kesimpulannya. Dalam penelitan ini yang menjadi populasi adalah seluruhkaryawan tetap PT. Tozy Sentosa Cabang Yogyakarta yang berjumlah 65 orang.

Sampel adalah sebagian dari jumlah dan karakteristik yang dimiliki olehpopulasi tersebut ( Sugiyono, 2002 ). Sampel diambil berdasarkan randomsampling (probability sampling), dengan teknik stratified random sampling.Jumlah sampel dalam penelitian ini adalah 40 karyawan PT. Tozy Sentosa Cabang Yogyakarta

Sumber penelitian berasal dari data primer.Data primer adalah data yang langsung dan segera dapat diperoleh dari sumbernya, diamati, dan dicatat pertama kalinya. Dalam penelitian ini data primer yang digunakan bersumber dari responden yang merupakan karyawan PT Tozy Sentosa Cabang Yogyakarta, yang terdiri dari identitas responden, tanggapan responden terhadap motivasi kerja, pengembangan karir, kompensasi, dan kepuasan karyawan.

Metode pengumpulan data yang digunakan dalam penelitian ini adalah dengan membagikan angket langsung kepada karyawan PT Tozy Sentosa( Centro Lifestyle Department Store ) Cabang Yogyakarta. Pembagian angket bertujuan untuk mendaparkan data primer, seperti mengetahui pendapat responden mengenai motivasi kerja, pengembangan karir, kompensasi dan kepuasan kerja karyawan.Sedangkan data sekunder diperoleh dari data yang diberikan oleh perusahaan, seperti kebijakan motivasi,kebijakan penggajian, kebijakan jenjang karir dan sejarah perusahaan.

Berdasarkan tujuan dari penelitian ini, maka beberapa metoda analisis datayang akan digunakan dalam penelitian ini adalah sebagai berikut :

1. Uji Instrumen

a. Uji Validitas

Uji validitas digunakan untuk mengukur sah atau valid tidaknya suatukuesioner. Suatu kuesioner dikatakan valid jika pertanyaan pada kuesionermampu untuk mengungkapkan sesuatu yang akan diukur oleh kuesioner tersebut( Imam Ghozali, 2005). Untuk mengukur validitas dapat dilakukan denganmelakukan korelasi antar skor butir pertanyaan dengan total skor konstruk atauvariabel. Sedangkan untuk mengetahui skor masing - masing item pertanyaanvalid atau tidak, maka ditetapkan kriteria statistik sebagai berikut :

1) Jika $r$ hitung $>r$ tabel dan bernilai positif, maka variabel tersebut valid.

2) Jika $r$ hitung $<r$ tabel, maka variabel tersebut tidak valid.

3) Jika $r$ hitung $>r$ tabel tetapi bertanda negatif, maka H0 akan tetap ditolak danH1 diterima.

b. Uji Reliabilitas

Uji reliabilitas adalah alat untuk mengukur suatu kuisioner yangmempunyai indikator dari variabel atau konstruk. Suatu kuisioner dinyatakanreliabel atau handal jika jawaban seseorang terhadap pernyataan adalah konsistenatau stabil dari waktu ke waktu (Ghozali, 2005).Uji reliabilitas dapat dilakukan dengan menggunakan bantuan programSPSS, yang akan memberikan fasilitas untuk mengukur reliabilitas dengan ujistatistik Cronbach Alpha ( $\alpha$ ). Suatu konstruk atau variabel dikatakan reliabel jikamemberikan nilai Cronbanch Alpha > 0,60

2. Uji Model

a. Koefisien Determinasi (R2)

Koefisien determinasi pada intinya mengukur seberapa jauh kemampuanmodel dalam menerangkan variasi variabel independen.Nilai koefisiendeterminasi adalah antara nol dan satu.Nilai R2 yang 
kecil berarti kemampuanvariabel-variabel independen dalam menjelaskan variasi variabel dependen amatterbatas.Nilai yang mendekati satu berarti variabel-variabel independenmemberikan hampir semua informasi yang dibutuhkan untuk memprediksi variasivariabel dependen (Imam Gozali, 2005).

b. Uji F

Uji $F$ digunakan pada dasarnya menunjukkan apakah semua variabelindependen atau bebas yang dimasukkan dalam model mempunyai pengaruhsecara bersama-sama terhadap variabel dependen atau terikat (Imam Ghozali, 2005).

Langkah-langkah pengujiannya adalah sebagai berikut :

1) Derajat kepercayaan $=5 \%$

2) Derajat kebebasan $\mathrm{f}$ tabel $(\alpha, \mathrm{k}, \mathrm{n}-\mathrm{k}-1)$ $\alpha=0,05$

$\mathrm{k}=$ jumlah variabel bebas

$\mathrm{n}=$ jumlah sampel

3) Menentukan kriteria pengujian H0 ditolak apabila f hitung $>\mathrm{f}$ tabel HA ditolak apabila $\mathrm{f}$ hitung $<\mathrm{f}$ tabel

4) Menentukan $f$ dengan rumus $\mathrm{f} \quad=\mathrm{R} 2 / \mathrm{k}$ $(\overline{1-\mathrm{R} 2) /(\mathrm{n}-\mathrm{k}-1)}$

R2 = koefisien determinan berganda

$\mathrm{n} \quad=$ jumlah sampel

$\mathrm{k} \quad=$ jumlah variabel bebas

Kesimpulan :

Apabila $\mathrm{f}$ hitung $<\mathrm{f}$ tabel maka $\mathrm{H} 0$ diterima dan HA ditolak, artinya tidak adapengaruh secara simultan.

Apabila $\mathrm{f}$ hitung $>\mathrm{f}$ tabel maka H0 ditolak dan HA diterima, artinya adapengaruh secara simultan.

3. Uji Asumsi Klasik

a. Uji Normalitas

Uji asumsi normalitas bertujuan untuk menguji apakah dalam modelregresi, variabel pengganggu atau residual memiliki distribusi normal atau tidak.Distribusi normal akan membentuk satu garis lurus diagonal, dan ploting dataresidual akan dibandingkan dengan garis diagonal. Jika distribusi data residualnormal, maka garis yang menggambarkan data sesungguhnya akan mengikutigaris diagonalnya. Dasar pengambilan keputusan memenuhi normalitas atau tidak,sebagai berikut :

1) Jika data menyebar disekitar garis diagonal dan mengikuti arah garis diagonal atau grafik histogramnya menunjukkan pola distribusi normal, maka modelregresi memenuhi asumsi normalitas.

2) Jika data menyebar jauh dari diagonal dan/atau tidak mengikuti arah garisdiagonal atau grafik histogram tidak menunjukkan pola distribusi normal,maka regresi tidak memenuhi asumsi normalitas.

b. Linearitas

Uji linearitas digunakan untuk melihat apakah model yang dibangunmempunyai hubungan yang linear atau tidak.Model dibentuk berdasarkantinjauan teoritis bahwa hubungan antara variabel independen dengan variabeldependennya adalah linear.Uji linearitas digunakan untuk mengkonfirmasiapakah sifat linear antar dua variabel yang diidentifikasikan secara teori sesuaidengan hasil observasi yang ada. Mengingat penelitian ini menggunakan Analisis Jalur (Path Analysis),maka terdapat beberapa asumsi dasar untuk memenuhi kaedah Trimming Theory(Teori Trimming), di antaranya :

1) Hubungan antar variabel harus bersifat linear.

2) Model penelitian memiliki hubungan kausalitas dengan panah satuarah / oneway causal flow (recursive model). Pengujian dilakukansecara parsial dengan OLS (analisis regresi).

3) Variabel endogen minimal dalam skala interval.

4) Instrumen penelitian harus reliabel dan valid (variabel diukur tanpakesalahan).

5) Model penelitian sesuai dengan teori dan konsep.

4. Analisis Regresi Linier

Analisis regresi linier digunakan untuk mengetahui ada tidaknyapengaruh antara motivasi, pengembangan karir dan kompensasi terhadap kepuasan kerja karyawan.Dalam regresi linier berganda terdapat 4 variabel, yaitu

1) Variabel Bebas ( X1 ), yaitu Motivasi 
2) Variabel bebas ( X2 ), yaitu Pengembangan Karir

3) Variabel bebas (X3), yaitu Kompensasi

4) Variabel Terikat ( Y ), yaitu Kepuasan Kerja

Untuk menguji variabel tersebut maka digunakan analisa regresi linierberganda dengan rumus sebagai berikut:

$\mathrm{Y}=\mathrm{a}+\mathrm{bX}+\mathrm{e}$

$\mathrm{Y}=\mathrm{a}+\mathrm{b} 1 \mathrm{X} 1+\mathrm{b} 2 \mathrm{X} 2+\mathrm{b} 3 \mathrm{X} 3+\mathrm{e}$

Dimana :

$$
\begin{array}{ll}
\mathrm{a} & =\text { konstanta } \\
\mathrm{Y} & =\text { kepuasan kerja karyawan } \\
\mathrm{b} 1, \mathrm{~b} 2, \mathrm{~b} 3 & =\text { koefisien garis regresi } \\
\mathrm{X} 1 & =\text { motivasi } \\
\mathrm{X} 2 & =\text { pengembangan karir } \\
\mathrm{X} 3 & =\text { kompensasi } \\
\mathrm{e} & =\text { residual atau prediction error }
\end{array}
$$

a. Uji t ( regresi parsial )

1) Menentukan formulasi hipotesis

Ho : $\mathrm{b} 1=0$ artinya, tidak ada pengaruh dari masing-masing variabel bebas $(\mathrm{x})$ terhadap variable terikat $(\mathrm{y})$.

Ha : $\mathrm{b} 1 \neq 0$ artinya, ada pengaruh dari masing-masing variabel bebas
( $\mathrm{x}$ ) terhadap variable terikat ( $\mathrm{y})$.

2) Menentukan derajat kepercayaan 95\% ( $\alpha=0.05$ ).

3) Menentukan signifikansi nilai signifikansi ( $P$ value $) \leq 0,05$, maka Ho ditolak dan Ha diterima.

nilai signifikansi ( $P$ value $)>0,05$, maka Ho diterima dan Ha ditolak.

b. Uji f ( regresi simultan )

1) Menentukan formulasi hipotesis

Ho : $\mathrm{b} 1=0$ artinya, semua variabel bebas ( $\mathrm{x}$ ) secara simultan tidak mempengaruhi variable terikat ( $\mathrm{y}$ ).

Ha : b1 $\neq 0$ artinya, semua varibael bebas ( $\mathrm{x}$ ) secara simultan mempengaruhi variable terikat ( y ).

2) Menentukan derajat kepercayaan 95\% ( $\alpha=0,05$ ).

3) Menentukan signifikansi nilai signifikansi $(P$ value $) \leq 0,05$, maka Ho ditolak dan Ha diterima.

nilai signifikansi ( $P$ value $)>0,05$,

\begin{tabular}{|c|c|c|c|c|c|c|c|c|}
\hline & & X1_1 & X1_2 & X1_3 & X1_4 & X1_5 & X1_6 & $\mathrm{X} 1$ \\
\hline \multirow[t]{3}{*}{ X1_1 } & Pearson Correlation & 1 &,- 202 &, 046 &, 271 & ,067 & ,130 & ,218 \\
\hline & Sig. (2-tailed) & & ,333 & ,829 & ,189 & ,751 & ,537 & ,295 \\
\hline & $\mathrm{N}$ & 25 & 25 & 25 & 25 & 25 & 25 & 25 \\
\hline \multirow[t]{3}{*}{ X1_2 } & Pearson Correlation &,- 202 & 1 & 703 & ,189 & ,345 & 611 &, 745 \\
\hline & Sig. (2-tailed) & ,333 & &, 000 & ,366 & ,091 & ,001 &, 000 \\
\hline & $\mathrm{N}$ & 25 & 25 & 25 & 25 & 25 & 25 & 25 \\
\hline \multirow[t]{3}{*}{ X1_3 } & Pearson Correlation & ,046 &, 703 & 1 & ,395 & ,608" &, 514 & $893^{\prime \prime}$ \\
\hline & Sig. (2-tailed) & ,829 &, 000 & & ,051 & ,001 & ,009 &, 000 \\
\hline & $\mathrm{N}$ & 25 & 25 & 25 & 25 & 25 & 25 & 25 \\
\hline \multirow[t]{3}{*}{ X1_4 } & Pearson Correlation & ,271 & , 189 & ,395 & 1 & ,377 & ,316 & 619 \\
\hline & Sig. (2-tailed) & ,189 & ,366 & ,051 & & ,063 & ,123 &, 001 \\
\hline & $\mathrm{N}$ & 25 & 25 & 25 & 25 & 25 & 25 & 25 \\
\hline \multirow[t]{3}{*}{ X1_5 } & Pearson Correlation & ,067 & ,345 & $608^{\prime \prime}$ & ,377 & 1 & ,106 &, 666 \\
\hline & Sig. (2-tailed) & ,751 & ,091 &, 001 & ,063 & & ,613 &, 000 \\
\hline & $\mathrm{N}$ & 25 & 25 & 25 & 25 & 25 & 25 & 25 \\
\hline \multirow[t]{3}{*}{ X1_6 } & Pearson Correlation & , 130 &, $611^{\prime \prime}$ &, 514 & ,316 & ,106 & 1 &, 690 \\
\hline & Sig. (2-tailed) &, 537 & ,001 &, 009 & ,123 & ,613 & &, 000 \\
\hline & $\mathrm{N}$ & 25 & 25 & 25 & 25 & 25 & 25 & 25 \\
\hline
\end{tabular}
maka Ho diterima dan $\mathrm{Ha}$ ditolak

\section{Hasil dan Pembahasan}

Hasil Uji Instrumen

Validitas dan Reliabilitas X dan Y

$\mathrm{X} 1$

Correlations 
JURNAL MANAJEMEN VOL 5 NO.1 JUNI 2015

\begin{tabular}{|ll|r|r|r|r|r|r|r|}
\hline X1 Pearson Correlation &, 218 &, $745^{\prime \prime}$ &, $893^{\prime \prime}$ &, $619^{\prime \prime}$ &, 666 &, 690 & \\
& Sig. (2-tailed) &, 295 &, 000 &, 000 &, 001 &, 000 &, 000 & 1 \\
& $\mathrm{~N}$ & 25 & 25 & 25 & 25 & 25 & 25 & 25 \\
\hline
\end{tabular}

${ }^{\star \star}$. Correlation is significant at the 0.01 level (2-tailed).

Reliability Statistics

\begin{tabular}{|r|r|}
\hline Cronbach's Alpha & N of Items \\
\hline, 750 & 6 \\
\hline
\end{tabular}

X2

\section{Correlations}

\begin{tabular}{|c|c|c|c|c|c|c|c|c|}
\hline & & $X 2 \_1$ & $X 2 \_2$ & X2_3 & $X 2 \_4$ & $\times 2 \_5$ & X2_6 & $\mathrm{X} 2$ \\
\hline \multirow[t]{3}{*}{$\mathrm{X} 2 \_1$} & Pearson Correlation & 1 &, 542 &, 460 &, 914 &, 155 &,- 110 &, $703^{\pi m}$ \\
\hline & Sig. (2-tailed) & &, 005 &, 021 &, 000 & ,461 & ,601 &, 000 \\
\hline & $\mathrm{N}$ & 25 & 25 & 25 & 25 & 25 & 25 & 25 \\
\hline \multirow[t]{3}{*}{ X2_2 } & Pearson Correlation &, 542 & 1 &, $717^{\pi \prime \prime}$ &, $537^{\pi \prime}$ & ,358 &,- 091 &, 849 \\
\hline & Sig. (2-tailed) &, 005 & &, 000 &, 006 & ,079 &, 664 &, 000 \\
\hline & $\mathrm{N}$ & 25 & 25 & 25 & 25 & 25 & 25 & 25 \\
\hline \multirow[t]{3}{*}{ X2_3 } & Pearson Correlation &, 460 &, $717^{\prime \prime}$ & 1 & 4 & ,473 &,- 063 & ,834" \\
\hline & Sig. (2-tailed) & ,021 &, 000 & & ,037 & ,017 &, 764 &, 000 \\
\hline & $\mathrm{N}$ & 25 & 25 & 25 & 25 & 25 & 25 & 25 \\
\hline \multirow[t]{3}{*}{$\mathrm{X} 2 \_4$} & Pearson Correlation & 914 &, $537^{\prime \prime}$ & ,419 & 1 & ,162 &,- 203 &, 674 \\
\hline & Sig. (2-tailed) &, 000 &, 006 & ,037 & & ,439 & ,331 & ,000 \\
\hline & $\mathrm{N}$ & 25 & 25 & 25 & 25 & 25 & 25 & 25 \\
\hline \multirow[t]{3}{*}{ X2_5 } & Pearson Correlation & , 155 & ,358 & $473^{\circ}$ & ,162 & 1 & , 170 &, $629^{* \pi}$ \\
\hline & Sig. (2-tailed) & ,461 & ,079 &, 017 & ,439 & & ,418 &, 001 \\
\hline & $\mathrm{N}$ & 25 & 25 & 25 & 25 & 25 & 25 & 25 \\
\hline \multirow[t]{3}{*}{$X 2 \_6$} & Pearson Correlation &,- 110 &,- 091 &,- 063 &,- 203 & ,170 & 1 & ,129 \\
\hline & Sig. (2-tailed) &, 601 & ,664 & ,764 & ,331 & ,418 & & ,539 \\
\hline & $\mathrm{N}$ & 25 & 25 & 25 & 25 & 25 & 25 & 25 \\
\hline \multirow[t]{3}{*}{$\mathrm{X} 2$} & Pearson Correlation & ,703 & ,849" &, 834 & $674^{\prime \prime}$ & 629 & , 129 & 1 \\
\hline & Sig. (2-tailed) &, 000 &, 000 &, 000 & ,000 & ,001 & ,539 & \\
\hline & $\mathrm{N}$ & 25 & 25 & 25 & 25 & 25 & 25 & 25 \\
\hline
\end{tabular}

**. Correlation is significant at the 0.01 level (2-tailed).

*. Correlation is significant at the 0.05 level (2-tailed).

Reliability Statistics

\begin{tabular}{|r|r|}
\hline Cronbach's Alpha & N of Items \\
\hline, 727 & 6 \\
\hline
\end{tabular}

X3

Correlations

\begin{tabular}{|c|c|c|c|c|c|c|c|}
\hline & & X3_1 & X3_2 & X3_3 & X3 4 & X3 5 & X3 \\
\hline \multirow[t]{3}{*}{ X3_1 } & Pearson Correlation & 1 &, 500 & ,229 & ,352 &, 333 &, $666^{\prime \prime}$ \\
\hline & Sig. (2-tailed) & & ,011 & ,270 & ,085 & ,103 &, 000 \\
\hline & $\mathrm{N}$ & 25 & 25 & 25 & 25 & 25 & 25 \\
\hline \multirow[t]{3}{*}{ X3_2 } & Pearson Correlation &, 500 & 1 & ,204 & ,494 & ,389 &, 749 \\
\hline & Sig. (2-tailed) &, 011 & & ,328 &, 012 & ,055 &, 000 \\
\hline & $\mathrm{N}$ & 25 & 25 & 25 & 25 & 25 & 25 \\
\hline \multirow[t]{3}{*}{ X3_3 } & Pearson Correlation & ,229 & 204 & 1 & ,352 & ,688" & ,641" \\
\hline & Sig. (2-tailed) & 270 & ,328 & & ,085 &, 000 &, 001 \\
\hline & $\mathrm{N}$ & 25 & 25 & 25 & 25 & 25 & 25 \\
\hline \multirow[t]{3}{*}{ X3_4 } & Pearson Correlation & ,352 & ,494 & ,352 & 1 & ,427 &, 770 \\
\hline & Sig. (2-tailed) & ,085 & ,012 & ,085 & & ,033 & ,000 \\
\hline & $\mathrm{N}$ & 25 & 25 & 25 & 25 & 25 & 25 \\
\hline X3_5 & $\begin{array}{l}\text { Pearson Correlation } \\
\text { Sig. (2-tailed) }\end{array}$ & $\begin{array}{l}333 \\
.103\end{array}$ & $\begin{array}{l}389 \\
.055\end{array}$ & $\begin{array}{r}.688 \\
.000\end{array}$ & $\begin{array}{r}, 427 \\
.033\end{array}$ & 1 & $\begin{array}{r}, 760 " \\
000\end{array}$ \\
\hline
\end{tabular}


JURNAL MANAJEMEN VOL 5 NO.1 JUNI 2015

\begin{tabular}{|c|c|c|c|c|c|c|c|}
\hline & $\mathrm{N}$ & 25 & 25 & 25 & 25 & 25 & 25 \\
\hline X3 & $\begin{array}{l}\text { Pearson Correlation } \\
\text { Sig. (2-tailed) }\end{array}$ & $\begin{array}{r}, 666 \\
.000\end{array}$ & $\begin{array}{r}.749 \\
.000\end{array}$ & $\begin{array}{r}.641 \\
.001\end{array}$ & $\begin{array}{r}.770 \\
.000\end{array}$ & $\begin{array}{r}.760 \\
.000\end{array}$ & 1 \\
\hline & $\mathrm{N}$ & 25 & 25 & 25 & 25 & 25 & 25 \\
\hline
\end{tabular}

*. Correlation is significant at the 0.05 level (2-tailed).

**. Correlation is significant at the 0.01 level (2-tailed).

Reliability Statistics

\begin{tabular}{|r|r|}
\hline Cronbach's Alpha & N of Items \\
\hline, 761 & 5 \\
\hline
\end{tabular}

correlations

\begin{tabular}{|c|c|c|c|c|c|c|c|c|}
\hline & & $\mathrm{Y}_{1}$ & Y2 & Y3 & Y4 & Y5 & Y6 & Y \\
\hline \multirow[t]{3}{*}{ Y1 } & Pearson Correlation & 1 &,- 059 & ,068 & ,403 &, 158 &, 054 &, $449^{\circ}$ \\
\hline & Sig. (2-tailed) & & ,780 & ,747 & ,046 & ,451 & ,798 & ,024 \\
\hline & $\mathrm{N}$ & 25 & 25 & 25 & 25 & 25 & 25 & 25 \\
\hline \multirow[t]{3}{*}{ Y2 } & Pearson Correlation &,- 059 & 1 & ,239 & ,013 & , 180 & ,172 & ,375 \\
\hline & Sig. (2-tailed) &, 780 & & ,250 & ,949 & ,388 & ,411 & ,065 \\
\hline & $\mathrm{N}$ & 25 & 25 & 25 & 25 & 25 & 25 & 25 \\
\hline \multirow[t]{3}{*}{ Y3 } & Pearson Correlation & ,068 & ,239 & 1 & ,468 & ,215 & 406 & ,623 \\
\hline & Sig. (2-tailed) & ,747 & ,250 & & ,018 & ,302 &, 044 &, 001 \\
\hline & $\mathrm{N}$ & 25 & 25 & 25 & 25 & 25 & 25 & 25 \\
\hline \multirow[t]{3}{*}{ Y4 } & Pearson Correlation & 403 & ,013 & 4 & 1 & ,347 & ,332 &, 726 \\
\hline & Sig. (2-tailed) &, 046 & ,949 & ,018 & & ,090 &, 105 &, 000 \\
\hline & $\mathrm{N}$ & 25 & 25 & 25 & 25 & 25 & 25 & 25 \\
\hline \multirow[t]{3}{*}{ Y5 } & Pearson Correlation & , 158 & , 180 & ,215 & ,347 & 1 &, $538^{m}$ & ,709" \\
\hline & Sig. (2-tailed) & ,451 & ,388 & ,302 & ,090 & &, 006 &, 000 \\
\hline & $\mathrm{N}$ & 25 & 25 & 25 & 25 & 25 & 25 & 25 \\
\hline \multirow[t]{3}{*}{ Y6 } & Pearson Correlation & ,054 & ,172 & ,406 & ,332 &, $538^{\prime \prime}$ & 1 & ,720" \\
\hline & Sig. (2-tailed) & ,798 & ,411 &, 044 & ,105 &, 006 & &, 000 \\
\hline & $\mathrm{N}$ & 25 & 25 & 25 & 25 & 25 & 25 & 25 \\
\hline \multirow[t]{3}{*}{$\mathrm{Y}$} & Pearson Correlation & ,449 & ,375 &, 623 &, 726 &, 709 & ,720 & 1 \\
\hline & Sig. (2-tailed) & ,024 & ,065 &, 001 & ,000 &, 000 & ,000 & \\
\hline & $\mathrm{N}$ & 25 & 25 & 25 & 25 & 25 & 25 & 25 \\
\hline
\end{tabular}

*. Correlation is significant at the 0.05 level (2-tailed).

**. Correlation is significant at the 0.01 level (2-tailed).

Reliability Statistics

\begin{tabular}{|r|r|}
\hline Cronbach's Alpha & N of Items \\
\hline, 660 & 6 \\
\hline
\end{tabular}

Dari hasil pengujian validitas pada tabel diatas dapat dilihat bahwa ada item pertanyaan yang tidak valid yaitu variabel motivasi item no 1 , variabel pengembangan karir item no 6 , dan variabel kepuasan kerja pada item no 2 karena nilai $r$ hitung kurang dari $r$ tabel $(0,396)$ dan nilai signifikansi lebih dari 0,05. Item pertanyaan yang tidak valid dikeluarkan dari kuesioner dan item pertanyaan yang valid digunakan dalam penelitian selanjutnya.

Berdasarkan

hasil

nilai koefisienCronbach's Alphaseluruh variabel memiliki menunjukkan nilai koefisien Cronbach's Alpha> 0,600. Hal ini mengindikasikan bahwa setiap instrumen penelitian ini memiliki tingkat reliabilitas/kehandalan yang baik. 


\section{JURNAL MANAJEMEN VOL 5 NO.1 JUNI 2015}

Hasil Uji Normalitas

One-Sample Kolmogorov-Smirnov Test

\begin{tabular}{|ll|r|r|r|r|}
\hline & & motivasi & karir & Kompensasi & kepuasan \\
\hline N & & 40 & 40 & 40 & 40 \\
& Mean & 3,7800 & 3,7250 & 3,7750 & 3,7000 \\
& Std, Deviation &, 50393 &, 49134 &, 48609 &, 47068 \\
Most Extreme Differences & Absolute &, 191 &, 161 &, 178 &, 138 \\
& Positive &, 102 &, 113 &, 122 &, 088 \\
& Negative &,- 191 &,- 161 &,- 178 &,- 138 \\
Kolmogorov-Smirnov Z & & 1,207 & 1,016 & 1,128 \\
Asymp, Sig, (2-tailed) & &, 109 &, 253 &, 157 &, 873 \\
\end{tabular}

a, Test distribution is Normal,

Histogram

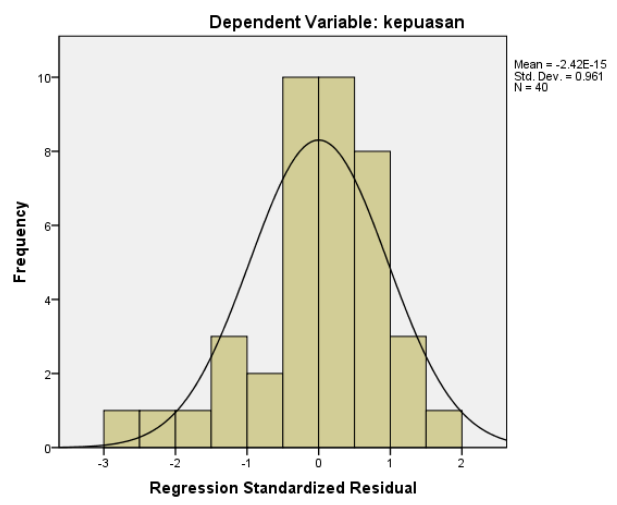

b, Calculated from data,

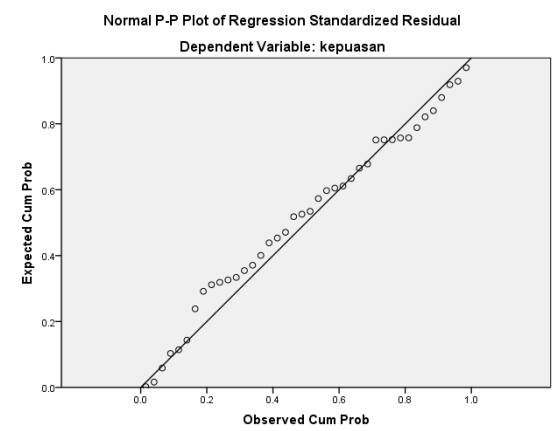

Hasil uji normalitas variabel penelitian dapat signifikansi lebih besar dari 0,05 (signifikansi diketahui bahwa semua variabel penelitian $>0,05$ ), sehingga dapat disimpulkan bahwa mempunyai nilai Zhitung dengan nilai semua variabel penelitian berdistribusi normal. 


\section{JURNAL MANAJEMEN VOL 5 NO.1 JUNI 2015}

Hasil Uji Linieritas

Case Processing Summary

\begin{tabular}{|c|c|c|c|c|c|c|}
\hline & \multicolumn{6}{|c|}{ Cases } \\
\hline & \multicolumn{2}{|c|}{ Included } & \multicolumn{2}{|c|}{ Excluded } & \multicolumn{2}{|c|}{ Total } \\
\hline & $\mathrm{N}$ & Percent & $\mathrm{N}$ & Percent & $\mathrm{N}$ & Percent \\
\hline kepuasan ${ }^{*}$ motivasi & 40 & $100,0 \%$ & 0 &, $0 \%$ & 40 & $100,0 \%$ \\
\hline kepuasan ${ }^{*}$ karir & 40 & $100,0 \%$ & 0 &, $0 \%$ & 40 & $100,0 \%$ \\
\hline kepuasan * Kompensasi & 40 & $100,0 \%$ & 0 &, $0 \%$ & 40 & $100,0 \%$ \\
\hline
\end{tabular}

kepuasan * motivasi

Report

kepuasan

\begin{tabular}{|c|c|c|c|}
\hline motivasi & $\begin{array}{c}\text { Mea } \\
n\end{array}$ & $\mathrm{~N}$ & Std, Deviation \\
\hline 2,00 & $\begin{array}{r}2,80 \\
00\end{array}$ & 1 & \\
\hline 2,60 & $\begin{array}{r}3,00 \\
00\end{array}$ & 1 & , \\
\hline 3,20 & $\begin{array}{r}3,15 \\
00\end{array}$ & 4 & ,19149 \\
\hline 3,40 & $\begin{array}{r}3,40 \\
00\end{array}$ & 3 & ,40000 \\
\hline 3,60 & $\begin{array}{r}3,70 \\
00\end{array}$ & 4 & ,47610 \\
\hline 3,80 & $\begin{array}{r}3,67 \\
27\end{array}$ & 11 & ,43149 \\
\hline 4,00 & $\begin{array}{r}3,75 \\
00\end{array}$ & 4 & ,25166 \\
\hline 4,20 & $\begin{array}{r}4,07 \\
50\end{array}$ & 8 & ,23755 \\
\hline 4,40 & $\begin{array}{r}4,00 \\
00\end{array}$ & 3 & ,20000 \\
\hline 4,60 & $\begin{array}{r}4,60 \\
00\end{array}$ & 1 & , \\
\hline Total & $\begin{array}{r}3,70 \\
00\end{array}$ & 40 & ,47068 \\
\hline
\end{tabular}

ANOVA Table 
JURNAL MANAJEMEN VOL 5 NO.1 JUNI 2015

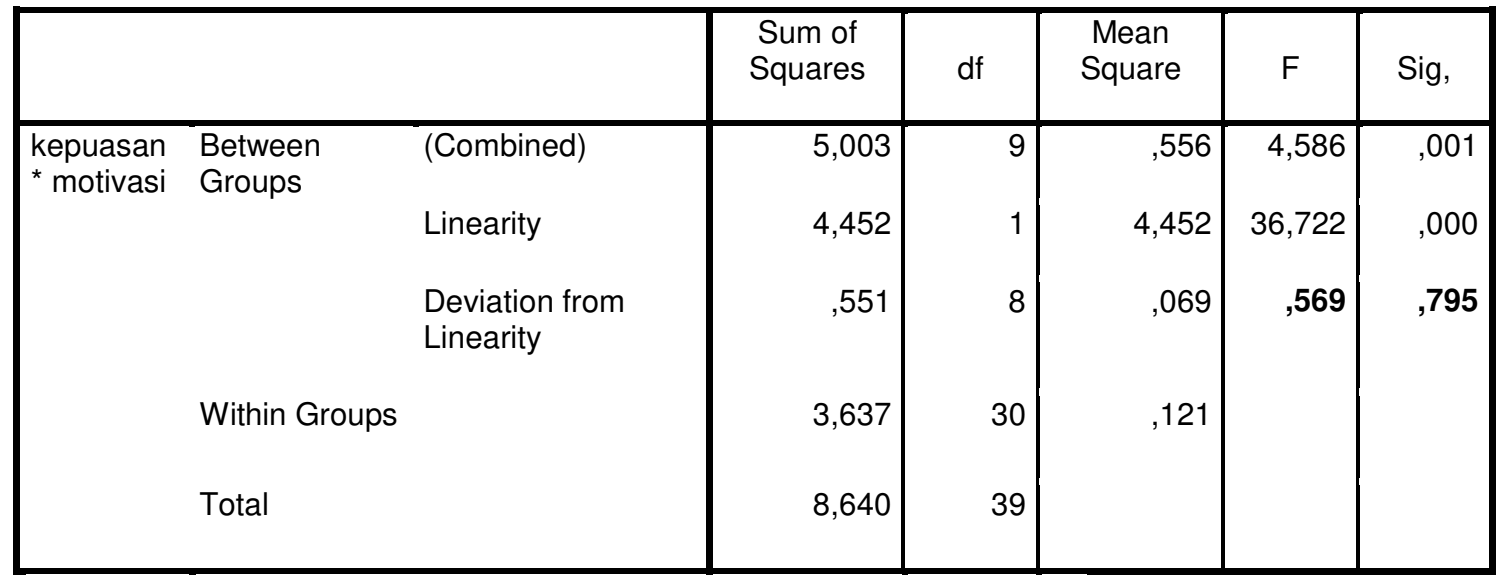

Measures of Association

\begin{tabular}{|l|r|r|r|r|}
\hline & \multicolumn{1}{|c|}{$\mathrm{R}$} & R Squared & Eta & Eta Squared \\
\hline $\begin{array}{l}\text { kepuasan * } \\
\text { motivasi }\end{array}$ &, 718 &, 515 &, 761 &, 579 \\
\hline
\end{tabular}

kepuasan * karir

Report

kepuasan

\begin{tabular}{|c|c|c|c|}
\hline karir & Mean & $\mathrm{N}$ & Std, Deviation \\
\hline 2,20 & 2,8000 & 1 & \\
\hline 2,40 & 3,0000 & 1 & , \\
\hline 3,00 & 3,0000 & 1 & , \\
\hline 3,20 & 3,2000 & 2 & ,00000 \\
\hline 3,40 & 3,3000 & 6 & 35214 \\
\hline 3,60 & 3,8400 & 5 & ,58992 \\
\hline 3,80 & 3,8444 & 9 & 26034 \\
\hline 4,00 & 3,8500 & 8 & 25635 \\
\hline 4,20 & 4,0500 & 4 & ,44347 \\
\hline 4,40 & 3,8000 & 1 & \\
\hline 4,60 & 4,2000 & 2 & ,56569 \\
\hline Total & 3,7000 & 40 & ,47068 \\
\hline
\end{tabular}


JURNAL MANAJEMEN VOL 5 NO.1 JUNI 2015

ANOVA Table

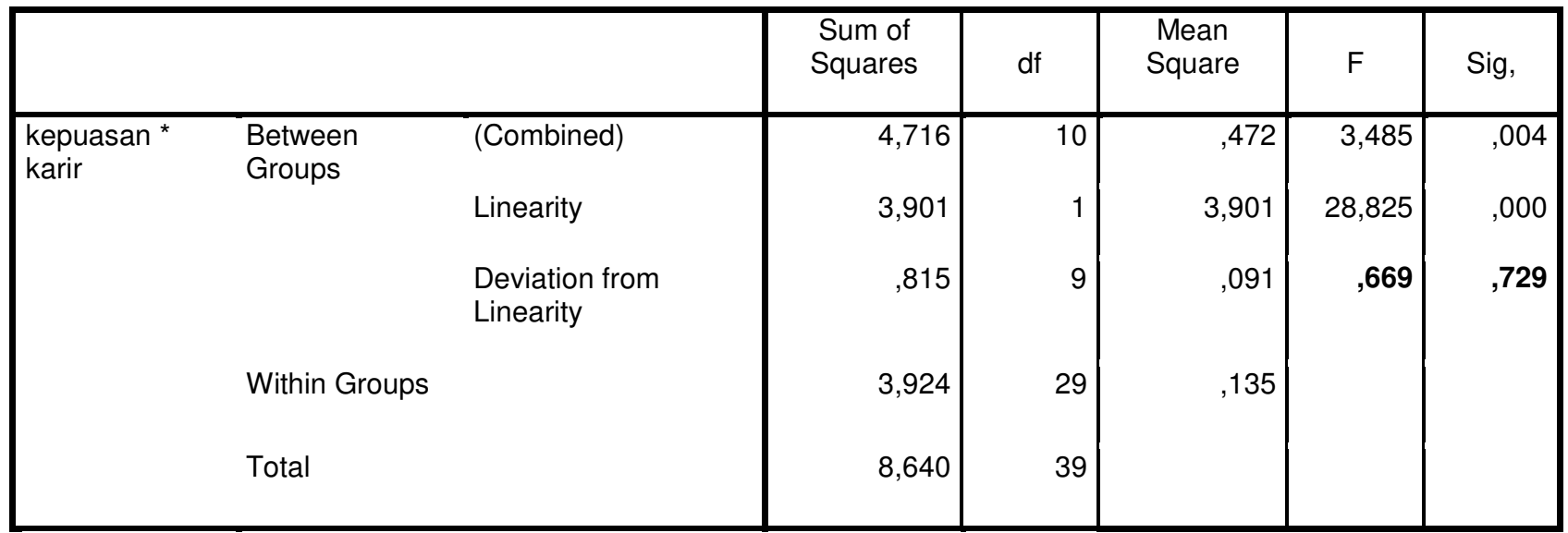

Measures of Association

\begin{tabular}{|l|r|r|r|r|}
\hline & $\mathrm{R}$ & $\mathrm{R}$ Squared & \multicolumn{1}{|c|}{ Eta } & Eta Squared \\
\hline kepuasan * karir &, 672 &, 451 &, 739 &, 546 \\
\hline
\end{tabular}

kepuasan * Kompensasi

Report

kepuasan

\begin{tabular}{|l|r|r|r|}
\hline Kompensasi & Mean & N & Std, Deviation \\
\hline 2,40 & 3,0000 & 1 &, \\
2,80 & 2,8000 & 1 &, 42426 \\
3,00 & 3,5000 & 2 &, 40000 \\
3,20 & 3,4000 & 3 &, 50332 \\
3,40 & 3,4667 & 3 &, 16330 \\
3,60 & 3,6000 & 4 &, 42740 \\
3,80 & 3,5667 & 6 &, 38573 \\
4,00 & 3,7167 & 12 &, 16733 \\
4,20 & 4,1600 & 5 &, 47068 \\
4,40 & 4,6000 & 1 &, \\
4,60 & 4,6000 & 1 &, \\
4,80 & 4,2000 & 40 &, 7000 \\
Total & 3,70 & \\
\hline
\end{tabular}


ANOVA Table

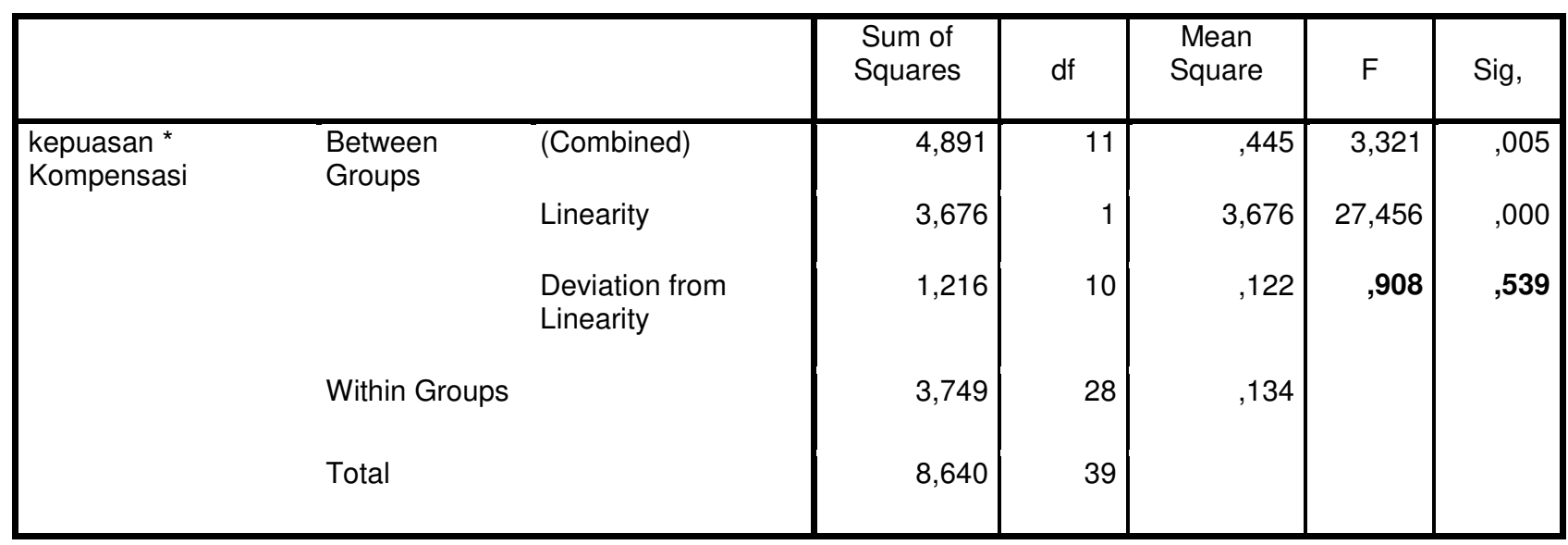

Measures of Association

\begin{tabular}{|l|r|r|r|r|}
\hline & $\mathrm{R}$ & $\mathrm{R}$ Squared & Eta & Eta Squared \\
\hline kepuasan * Kompensasi &, 652 &, 425 &, 752 &, 566 \\
\hline
\end{tabular}

Hasil uji linieritas dapat diketahui bahwa variabel independen terhadap variabel dependen mempunyai nilai signifikansi yang lebih dari 0,05 (signifikansi $>0,05$ ), hal ini menunjukkan bahwa semua variabel penelitian adalah linier.

\section{Hasil Uji Model dan Analisis Regresi}

\section{Variables Entered/Removed ${ }^{\mathrm{D}}$}

\begin{tabular}{|l|l|l|l|}
\hline Model & Variables Entered & $\begin{array}{l}\text { Variables } \\
\text { Removed }\end{array}$ & Method \\
\hline 1 & $\begin{array}{l}\text { Kompensasi, } \\
\text { karir, motivasi }\end{array}$ &, Enter \\
\hline
\end{tabular}
a, All requested variables entered,
b, Dependent Variable: kepuasan

Model Summary

\begin{tabular}{|l|r|r|r|r|}
\hline Model & $\mathrm{R}$ & R Square & \multicolumn{1}{|c|}{$\begin{array}{c}\text { Adjusted R } \\
\text { Square }\end{array}$} & $\begin{array}{c}\text { Std, Error of the } \\
\text { Estimate }\end{array}$ \\
\hline 1 &, $809^{\mathrm{a}}$ &, 654 &, 625 &, 28808 \\
\hline
\end{tabular}

a, Predictors: (Constant), Kompensasi, karir, motivasi 
JURNAL MANAJEMEN VOL 5 NO.1 JUNI 2015

Variables Entered/Removed ${ }^{\mathrm{b}}$

\begin{tabular}{|l|l|l|l|}
\hline Model & Variables Entered & $\begin{array}{l}\text { Variables } \\
\text { Removed }\end{array}$ & Method \\
\hline 1 & $\begin{array}{l}\text { Kompensasi, } \\
\text { karir, motivasi }\end{array}$ &, & Enter \\
\hline
\end{tabular}

ANOVA $^{b}$

\begin{tabular}{|c|c|c|c|c|c|}
\hline Model & Sum of Squares & $\mathrm{df}$ & Mean Square & $F$ & Sig, \\
\hline $\begin{array}{l}\text { Regression } \\
\text { Residual } \\
\text { Total }\end{array}$ & $\begin{array}{r}5,652 \\
2,988 \\
8,640\end{array}$ & $\begin{array}{r}3 \\
36 \\
39\end{array}$ & $\begin{array}{r}1,884 \\
, 083\end{array}$ & 22,704 &, $000^{\mathrm{a}}$ \\
\hline
\end{tabular}

a, Predictors: (Constant), Kompensasi, karir, motivasi

b, Dependent Variable: kepuasan

\section{Coefficients $^{a}$}

\begin{tabular}{|c|c|c|c|c|c|c|}
\hline \multirow{2}{*}{\multicolumn{2}{|c|}{ Model }} & \multicolumn{2}{|c|}{ Unstandardized Coefficients } & \multirow{2}{*}{$\begin{array}{c}\begin{array}{c}\text { Standardized } \\
\text { Coefficients }\end{array} \\
\text { Beta }\end{array}$} & \multirow[b]{2}{*}{$\mathrm{t}$} & \multirow[b]{2}{*}{ Sig, } \\
\hline & & B & Std, Error & & & \\
\hline \multirow[t]{4}{*}{1} & (Constant) & ,258 & ,423 & & ,609 &, 546 \\
\hline & motivasi & ,313 & ,133 & ,336 & 2,358 & ,024 \\
\hline & karir & 286 & ,127 & 299 & 2,256 & ,030 \\
\hline & Kompensasi & ,315 & ,116 & ,326 & 2,720 & ,010 \\
\hline
\end{tabular}

a, Dependent Variable: kepuasan

Dari hasil analisis regresi dapat diketahui persamaan regresi berganda sebagai berikut:

$\mathrm{Y}=0,2548+0,313 \mathrm{X}_{1}+0,286 \mathrm{X}_{2}+0,315 \mathrm{X}_{3}+\mathrm{e}$

Berdasarkan persamaan tersebut, maka dapat dijelaskan sebagai berikut:

a. Nilai konstanta sebesar 0,258dapat diartikan variabel kepuasan kerja akan mengalami peningkatan sebesar 0,258 atau $25,8 \%$ jika variabel motivasi, pengembangan karir, dan kompensasi konstan atau tidak mengalami perubahan.

b. Nilai koefisien beta pada variabel motivasi sebesar 0,313 artinya setiap peningkatan variabel motivasi $\left(\mathrm{X}_{1}\right)$ sebesar satu satuan maka akan mengakibatkan kepuasan kerja meningkatsebesar 0,313 satuan, dengan asumsi variabel yang lain tetap. Hasil ini mempunyai arah positif yang berarti semakin 
tinggi motivasi, maka semakin tinggi pula kepuasan kerja dan sebaliknya semakin rendah motivasi semakin rendah pula kepuasan kerja.

c. Nilai koefisien regresi pengembangan karir sebesar 0,286 berarti setiap pengembangan karir sebesar 1 satuan, akan diikuti dengan peningkatan kepuasan kerja sebesar 0,286 satuan, dengan asumsi variabel lain dalam kondisi konstan. Hasil ini berarti semakin tinggi pengembangan karir, maka semakin tinggi kepuasan kerja dan sebaliknya semakin rendah pengembangan karir, semakin rendah pula kepuasan kerja .

d. Nilai koefisien regresi kompensasisebesar 0,315 berarti setiap kompensasi sebesar 1 satuan, akan diikuti dengan peningkatan kepuasan kerja sebesar 0,315 satuan, dengan asumsi variabel lain dalam kondisi konstan. Hasil ini berarti semakin tinggi kompensasi, maka semakin tinggi kepuasan kerja dan sebaliknya semakin rendah kompensasi, semakin rendah pula kepuasan kerja .

e. Diketahui bahwa nilai $R$ Square regresi berganda antara variabel independen terhadap kepuasan kerja karyawan adalah 0,654. Hal ini menunjukan motivasi, pengembangan karir, dan kompensasi secara bersama-sama mempengaruhi kepuasan kerja karyawan sebesar $65,4 \%$, dan sisanya sebesar $34,6 \%$ kepuasan kerja karyawan dipengaruhi oleh faktor lain yang tidak diteliti dalam penelitian ini.

Terdapat pengaruh yang signifikan antara motivasi, pengembangan karir dan kompensasi terhadap kepuasan kerja karyawan PT. Tozy Sentosa ( Centro Lifestyle Department Store ) cabang Yogyakarta, baik secara parsial maupun stimulan.

Pimpinan perusahaan disarankan untuk selalu memperhatikan kesejahteraan karyawan dengan cara memberi motivasi, pengembangan karir bagi karyawan, dan kompensasi sebagai penghargaan prestasi yang di raih. Adanya penghargaan atau kesejahteraan akan memberikan semangat pada karyawan dalam bekerja. Pimpinan dalam perusahaan memiliki kewenangan untuk menentukan pembagian penghargaan yang berupa motivasi dan pengembangan karir.Untuk kompensasi dapat di design semenarik mungkin untuk kenyamanan karyawan dalam bekerja. Sebaiknya dilakukan penelitian lebih lanjut, peneliti yang akan datang disarankan untuk menambah sampel yang menjadi responden penelitian dengan meneliti tidak sebatas bagian tertentu saja. Apabila responden yang di teliti dari beberapa bagian devisi dengan pengambilan sampel perwakilan masing-masing bagian devisi perusahaan dan menambah jumlahnya responden, maka hasil penelitiannya akan mampu digeneralisasikan lebih luas lagi. Penelitian yang ingin meneliti lebih mendalam tentang faktor lain yang dapat mempengaruhi kepuasan kerja. Faktor lain yang di duga mempengaruhi kepuasan kerja seperti gaya kepemimpinan, sarana dan prasaran, fasilitas, hubungan kerja dengan sesama karyawan, dan komunikasi dengan atasan. Faktor ini di duga berpengaruh terhadap kepuasan kerja, sehingga untuk membuktikan dugaan tersebut dapat dilakukan penelitian selanjutnya.

\section{Referensi}

Ekayadi, Septyaningsih, 2009, Pengaruh Motivasi dan Pengembangan Karir terhadap Kepuasan Kerja Karyawan PT. Rimba Jati Raya Citra Karya, skripsi Universitas Gunadharma Jakarta.

Ghozali, Imam, 2005, Aplikasi Analisis Multivariate, Semarang : Badan Penerbit Universitas Diponegoro.

Hariandja, Marihot T.E, 2002. Manajemen Sumber Daya Manusia. Jakarta: Grasindo.

Hasibuan, Malayu S.P, 2005. Manajemen Sumber Daya Manusia. Jakarta: PT. Gunung Agung.

Nawawi, Hadari, 2003. Manajemen Sumber Daya Manusia, Yogyakarta: Gajah Mada University Press.40.

Prabu, Anwar, 2005. Pengaruh Motivasi Terhadap Kepuasan Kerja Pegawai 


\section{JURNAL MANAJEMEN VOL 5 NO.1 JUNI 2015}

$\begin{array}{lrrrrr}\text { BKKBN } & \text { Kabupaten } & \text { Muara } & \text { Enim. } & \text { Yogyakarta, skripsi } & \text { Universitas } \\ \text { Jurnal } & \text { Manajemen } & \text { dan } & \text { Bisnis } & \text { Sarjanawiyata Tamansiswa } & \end{array}$

Universitas Sriwijaya Vol 3 tanggal 6 Desember 2005.

Robbins, S. 2006. Organization Behavior, 9th $E d$.New Jersey, USA. Prentice-Hall International, Inc.

Saydam, Gouzali. 2000, Manajemen Sumber Daya Manusia (Human Resource) Suatu Pendekatan Mikro, Jakarta: Djanbatan

Sugijono.2011, Pengaruh Persepsi Kompensasi, Lingkungan Kerja, Kepemimpinan dan Motivasi terhadap Kepuasan Kerja Guru dan Karyawan SMK Tamansiswa Jetis

Sugiyono, dan Wibowo, Eri, 2002. Statistika untuk Penelitian dan Aplikasinya dengan SPSS 10.0 for Windows, Alfabeta, Bandung.

-2009, MetodePenelitianKuantitatif, Kualitatif dan $R \& D$. Bandung: Alfabeta.

Wahyudi, Bambang. 2002. Manajemen Sumber Daya Manusia. Bandung: Sulita.

Wibowo. 2007. Manajemen Kinerja. PT Rajagrafindo Persada, Jakarta. 